\title{
Diary Study sebagai Metode Pengumpulan Data pada Riset Kuantitatif: Sebuah Literature Review
}

\author{
Denisa Apriliawati \\ Prodi Psikologi, Fakultas Ilmu Sosial dan Humaniora, UIN Sunan Kalijaga \\ Jalan Laksda Adisucipto, DI. Yogyakarta \\ denisa.apriliawati@uin-suka.ac.id
}

\begin{abstract}
Some existing challenges in quantitative research are ecological validity in experimental psychology and recall bias in survey study. In order to answer those questions, the author was interested with experience sampling method (esm) or diary study. ESM is a research method that collects data frequently in participants' real world setting. This study performed systematic literature review to analyse the definition, procedures, as well as the benefits and drawbacks of ESM. According to the literature review, ESM is known to describe both intra-individual (within subject) and extra-individual (between subject) processes, has better ecological validity compared to experimental research, can minimize recall bias, and was able to obtain various data. Unfortunately, there were some drawbacks such as self-selction bias, attrition, motivation, also the complexity of its data management and analysis. Some procedures to minimize those issues have been discussed.
\end{abstract}

Keywords: diary study, experience sampling method, research methods, quantitative studies

Abstrak. Beberapa tantangan dalam penelitian kuantitatif yang masih belum bisa diatasi selama ini adalah validitas ekologis pada penelitian eksperimen dan recall bias pada penelitian survey. Guna menjawab permasalahan tersebut, penulis tertarik dengan penggunaan Diary Study/ Experience Sampling Method (ESM). ESM merupakan metode pengumpulan data secara berkala yang bersifat real-time di latar alami partisipan. Penelitian ini menggunakan metode systematic literature review untuk menganalisis definisi, prosedur serta kelebihan dan kekurangan ESM. Berdasar hasil telaah pustaka, ESM diketahui dapat menggambarkan proses inter maupun intra-individu, memiliki validitas ekologis yang bagus, meminimalisasi recall bias dan mendapatkan data yang beragam. Sayangnya, penggunaan ESM masih terkendala beberapa hal seperti self-selction bias, atrisi, motivasi serta kompleksnya managemen maupun teknik analisis data yang digunakan. Hal-hal yang dapat mengatasi permasalahan tersebut telah didiskusikan.

Kata kunci: diary study, experience sampling method, metode penelitian, penelitian kuantitatif

\section{Pendahuluan}

Perkembangan ilmu pengetahuan merupakan suatu keniscayaan. Sejauh ini, dalam konteks ilmu pengetahuan, tidak ada kebenaran yang bersifat mutlak. Hal ini juga berlaku pada keilmuan psikologi. Psikologi pada dasarnya adalah sains yang membahas mengenai perilaku manusia. Ilmu psikologi berkembang melalui proses berpikir dan proses penelitian yang menggunakan metode ilmiah.

Secara umum, ada tiga metode penelitian psikologi, yaitu: kualitatif, kuantitatif dan mixed method (Creswell, 2014). Creswell (2014, p. 32) menyebutkan bahwa ketiga metode penelitian ini berada pada satu kontinum di mana pendekatan kualitatif dan kuantitatif berada di dua ujung yang berbeda. Mixed 
methods kemudian digambarkan berada di tengah-tengah kontinum tersebut. Metode ini memfasilitasi baik karakteristik kualitatif maupun kuantitatif.

Metode penelitian kuantitatif sendiri merupakan pendekatan dalam metode penelitian psikologi yang melakukan pengetesan terhadap teori melalui studi terhadap hubungan variabel-variabel tertentu. Berbeda dengan kualitatif yang cenderung melihat kedalaman suatu peristiwa, pendekatan kuantitatif cenderung menyimplifikasi permasalahan dengan mengubah fenomena menjadi angka yang kemudian bisa dianalisis menggunakan statistika (Neuman, 2014, p. 17).

Metode pengumpulan data kuantitatif yang paling jamak digunakan dalam riset psikologi di Indonesia adalah survei dan eksperimen. Metode survei umum digunakan terutama ketika seorang peneliti ingin melihat gambaran situasi/variabel tertentu di dalam populasi melalui data yang diperoleh dari sampel tertentu yang mewakili populasi tersebut (Fowler, 2014, PP. 1-3). Contoh penelitian survey yang pernah dilakukan adalah survei mengenai personal hygiene pada remaja (Adila, Rinjani, \& Cinderela, 2019), atau survei mengenai pengetahuan dan sikap terhadap kekerasan (Prasandi \& Diana, 2020). Sementara itu metode penelitian eksperimen merupakan metode yang dapat mengetahui hubungan sebab akibat antara dua variabel atau lebih (Neuman, 2014). Metode eksperimen berbentuk RCT (Randomized Controlled Trial) bahkan merupakan golden standard penelitian psikologi. Beberapa contoh penelitian eksperimen banyak ditemukan di literatur saintifik Indonesia (lihat Muarif \& Adiyanti, 2020, dll.)

Hanya saja, data yang diperoleh melalui survei seringkali diganggu oleh keberadaan recall bias (i.e. ketidakakuratan dalam mengingat kembali fenomena) (lihat Ottenstein \& Lischetzke, 2020; Hipp et al., 2020; Gotlin et al., 2020). Trull dan Ebner-Priemer (2009) mengatakan bahwa recall bias seringkali muncul karena partisipan lebih memilih pengalaman yang relevan secara personal, pengalaman mutakhir, pengalaman yang menonjol atau pengalaman yang lebih sesuai dengan mood saat pengambilan data berlangsung. Sementara itu, pengaruh perlakuan dalam penelitian eksperimen seringkali diragukan karena rendahnya ecological validity (i.e. kemampuan menggeneralisasi hasil eksperimen ke lingkungan nyata subyek) (Lerner \& Schmid Callina, 2014; Schmuckler, 2001).

Experience sampling methods (ESM) atau yang biasa disebut dengan diary study merupakan metode pengambilan data secara berulang dalam jangka waktu tertentu yang dilakukan dalam kegiatan seharihari subyek (Scollon, et. al, 2003). Metode pengumpulan data menggunakan ESM memungkinkan peneliti untuk mengambil data real-time, di luar batasan laboratorium, dan dalam konteks kehidupan sehari-hari (Conner, et. al., 2003). ESM bisa digunakan untuk merekam variabel-variabel seperti memori, pikiran, perasaan, mood, dan perilaku (Barret \& Barret, 2001) yang bersifat episodik (i.e., terdiri atas beberapa peristiwa/kejadian yang saling berhubungan) di kehidupan sehari-hari (Conner, et. al., 2003). Hal ini tentunya kontras dengan pengukuran self-report standar yang cenderung mengukur gambaran umum suatu kejadian (bersifat semantik) (Conner, et. al., 2003). ESM berbeda dengan tiga metode pengumpulan momentary data lain, yaitu: thought-sampling (i.e., secara khusus mengukur pemikiran batin dengan mengabaikan peristiwa eksternal); descriptive-experience sampling (i.e., hanya mengumpulkan data kualitatif) dan ecological momentary assessment (i.e., memiliki karakter sama dengan ESM hanya saja, EMA juga mempertimbangkan elemen lingkungan yang berkaitan dengan pengalaman) (Christie N. Scollon, Kim-Prieto, \& Scollon, 2003).

ESM diinisiasi oleh Csikszentmihalyi et.al. pada tahun 1977 yang mempelajari mengenai remaja di lingkungan alamiah mereka dan juga oleh Branstaetter pada tahun 1983 mengenai moods di berbagai maca situasi (Christie N. Scollon et al., 2003). Meskipun hampir empat dekade telah berlalu semenjak ESM pertama kali dilakukan, riset-riset menggunakan metode ini di Indonesia masih terbatas. Pencarian menggunakan Google scholar dengan kata kunci "experience sampling methods" menghasilkan artikel yang hampir semuanya merupakan artikel berbahasa inggris dengan riset yang dilakukan di negara-negara barat. Sementara itu, melalui kata kunci "diary studies", "diary study", experience sampling method", dan "ESM" peneliti tidak menemukan satu artikel pun di https://sinta.ristekbrin.go.id/. Secara khusus, ESM masih terhitung sangat baru di Indonesia. Padahal, 
berdasarkan riset-riset yang telah dilakukan, ESM memiliki potensi yang besar dalam mengembangkan penelitian-penelitian di bidang perilaku, emosi, mood bahkan kecanduan zat adiktif semacam alkohol, narkoba dan rokok.

Oleh karena itu, peneliti melakukan studi literature review ini sebagai langkah awal penggunaan ESM sebagai metode pengambilan data kuantitatif di Indonesia. Secara garis besar, tulisan ini ditujukan untuk menjawab tiga pertanyaan utama, yaitu: apakah experience sampling method itu, bagaimana prosedur pelaksanaannya, dan apa saja kelebihan serta kekurangan experience sampling method?

\section{Metode}

Bab ini membahas proses pencarian jurnal, pertanyaan yang menjadi panduan saat review jurnal, serta batasan mengambil jurnal yang digunakan dalam literature review. Pencarian jurnal dilakukan melalui database penyedia jurnal internasional milik Google yaitu Google Scholar (scholar.google.com). Kata kunci yang digunakan adalah "diary study", "experience sampling method", dan "psychological research". Hasil pencarian ini memunculkan 13.500 artikel. Secara umum ada dua jenis artikel yang dipilih, pertama artikel kajian literature mengenai ESM dan artikel penelitian empiris yang menggunakan prosedur ESM. Selanjutnya artikel diseleksi berdasarkan beberapa karakteristik. Karakteristik artikel jenis pertama yang dijadikan patokan dalam proses seleksi artikel adalah menjelaskan mengenai definisi, prosedur dan karakteristik ESM. Sementara itu, jenis artikel yang kedua dipilih berdasarkan metode penelitian yang digunakan (ESM) dan merupakan studi di bidang psikologi. Penelitian tidak dipilih berdasarkan bahasa karena semua hasil yang diperoleh menggunakan Bahasa inggris. Selain itu, peneliti tidak mengutamakan tahun penerbitan terbaru karena ESM merupakan metode yang belum begitu dikenal di riset-riset psikologi kuantitatif di Indonesia sehingga peneliti lebih mengutamakan untuk mengambil sumber-sumber atau tokoh-tokoh kunci ESM. Berdasarkan proses seleksi ini diperoleh 14 artikel sebagai hasil pencarian sistematis.

Tabel 1. Ringkasan artikel mengenai ESM/Diary study

\begin{tabular}{|c|c|c|c|c|c|}
\hline No. & Studi & Negara & Metode & Analisis Ststistika & Hasil \\
\hline 1 & $\begin{array}{l}\text { Barret \& } \\
\text { Barret, } 2001\end{array}$ & USA & $\begin{array}{l}\text { Kualitatif, } \\
\text { Systematic } \\
\text { Literature } \\
\text { Review }\end{array}$ & - & $\begin{array}{ll}\text { Keunggulan komputerisasi } & \text { ESM } \\
\text { disbanding cara klasik } & \end{array}$ \\
\hline 2 & $\begin{array}{l}\text { Conner, et. } \\
\text { al., } 2003\end{array}$ & USA & $\begin{array}{l}\text { Kualitatif, } \\
\text { Systematic } \\
\text { Literature } \\
\text { Review }\end{array}$ & - & $\begin{array}{l}\text { Prosedur praktis pelaksanaan ESM } \\
\text { menggunakan komputerisasi, serta } \\
\text { penekanan pada pentingnya } \\
\text { kerjasama kelompok peneiti dalam } \\
\text { pelaksanaan ESM }\end{array}$ \\
\hline 3 & $\begin{array}{l}\text { Myin- } \\
\text { Germeys, } \\
\text { et. al., } 2003\end{array}$ & Netherlands & $\mathrm{ESM}, \mathrm{n}=175$ & $\begin{array}{l}\text { Multilevel } \\
\text { Regression } \\
\text { Analysis }\end{array}$ & $\begin{array}{l}\text { Terkait dengan situasi yang dirasa } \\
\text { penuh tekanan secara subyektif, } \\
\text { individu dengan major depressive } \\
\text { disorder cenderung mengalami } \\
\text { peningkatan negative affect, } \\
\text { individu dengan bipolar disorder } \\
\text { mengalami penurunan positive } \\
\text { affect dan individu dengan psikosis } \\
\text { mengalami kenaikan pada negative } \\
\text { affect dan penurunan positive affect } \\
\text { sekaligus. }\end{array}$ \\
\hline
\end{tabular}




\begin{tabular}{|c|c|c|c|c|c|}
\hline 4 & $\begin{array}{l}\text { Scollon, et. } \\
\text { al., } 2003\end{array}$ & Netherlands & $\begin{array}{l}\text { Kualitatif, } \\
\text { Systematic } \\
\text { Literature } \\
\text { Review }\end{array}$ & - & Kelebihan dan kekurangan ESM. \\
\hline 5 & $\begin{array}{l}\text { Myers, et. } \\
\text { al., } 2004\end{array}$ & USA & $\mathrm{ESM}, \mathrm{n}=279$ & $\begin{array}{l}\text { Factor analysis, t- } \\
\text { test, ANOVA, } \\
\text { correlation }\end{array}$ & $\begin{array}{l}\text { Kemunculan empat pola emosi yang } \\
\text { dialami manusia ketika melihat } \\
\text { binatang di kebun binatang. }\end{array}$ \\
\hline 6 & $\begin{array}{l}\text { Scollon, et. } \\
\text { al., } 2005\end{array}$ & USA & $\mathrm{ESM}, \mathrm{n}=386$ & $\begin{array}{l}\text { Descriptive } \\
\text { statistics, korelasi, } \\
\text { two-factors } \\
\text { analysis }\end{array}$ & $\begin{array}{l}\text { Mendapatkan pola mood negative } \\
\text { dan positif pada within dan between } \\
\text { subjects level. }\end{array}$ \\
\hline 7 & $\begin{array}{l}\text { Juslin, et. } \\
\text { al., } 2008\end{array}$ & Swedia & $\mathrm{ESM}, \mathrm{n}=32$ & $\begin{array}{l}\text { Descriptive } \\
\text { statistics, Pearson } \\
\text { Correlations }\end{array}$ & $\begin{array}{l}\text { Subyek mengalami perubahan emosi } \\
\text { ketika mendengarkan music. } \\
\text { Beberapa emosi bisa muncul secara } \\
\text { bersamaan saat mendengarkan } \\
\text { music (contoh:nostalgia-rindu) }\end{array}$ \\
\hline 8 & $\begin{array}{l}\text { Trull \& } \\
\text { Ebner- } \\
\text { Priemer, } \\
2009\end{array}$ & $\begin{array}{l}\text { USA \& } \\
\text { Germany }\end{array}$ & $\begin{array}{l}\text { Kualitatif, } \\
\text { Systematic } \\
\text { Literature }\end{array}$ & - & $\begin{array}{l}\text { Membandingkan ESM dengan EMA } \\
\text { dan penggunaannya dalam asesmen } \\
\text { dan penelitian klinis. }\end{array}$ \\
\hline 9 & $\begin{array}{l}\text { Hicks, et. } \\
\text { al., } 2010\end{array}$ & USA & $\begin{array}{l}\text { Kualitatif, } \\
\text { Systematic } \\
\text { Literature } \\
\text { Review }\end{array}$ & - & $\begin{array}{l}\text { Andwellness merupakan software } \\
\text { yang feasible digunakan dalam } \\
\text { proses pengumpulan data ESM. }\end{array}$ \\
\hline 10 & $\begin{array}{l}\text { Palmier- } \\
\text { Clauss, et. } \\
\text { al., } 2011\end{array}$ & $\begin{array}{l}\text { UK dan } \\
\text { Netherlands }\end{array}$ & $\begin{array}{l}\text { Kualitatif, } \\
\text { Systematic } \\
\text { Literature } \\
\text { Review }\end{array}$ & - & $\begin{array}{l}\text { Cara mendesain dan memvalidasi } \\
\text { ESM, penggunaan prosedur } \\
\text { sampling paling tepat dan } \\
\text { pentingnya komunikasi untuk } \\
\text { menjaga kepatuhan subyek, } \\
\text { penekanan pada debriefing dan } \\
\text { managemen data/analisis dan arah } \\
\text { perkembangan ESM di masa depan }\end{array}$ \\
\hline 11 & $\begin{array}{l}\text { Kelly, et. } \\
\text { al., } 2012\end{array}$ & UK & $\begin{array}{l}\text { Kualitatif, } \\
\text { Systematic } \\
\text { Literature } \\
\text { Review }\end{array}$ & - & $\begin{array}{l}\text { Pengembangan iRTT (intelligent real } \\
\text { time therapy) menggunakan ESM } \\
\text { untuk mencegah permasalahan } \\
\text { kesehatan mental yang kompleks. }\end{array}$ \\
\hline 12 & $\begin{array}{l}\text { Kashdan \& } \\
\text { Farmer, } \\
2014\end{array}$ & USA & $\mathrm{ESM}, \mathrm{n}=86$ & $\begin{array}{l}\text { Average interclass } \\
\text { correlation } \\
\text { Three-way } \\
\text { ANOVA }\end{array}$ & $\begin{array}{l}\text { Individu dengan Social } \text { Anxiety } \\
\text { Disorder cenderung lebih kesulitan } \\
\text { mengklarifikasi emosi negative } \\
\text { tertentu disbanding kelompok } \\
\text { control. }\end{array}$ \\
\hline 13 & $\begin{array}{l}\text { O'Toole, et. } \\
\text { al., } 2014\end{array}$ & Denmark & $\mathrm{ESM}, \mathrm{n}=264$ & $\begin{array}{l}\text { Multilevel linear } \\
\text { modelling }\end{array}$ & $\begin{array}{l}\text { Kelompok dengan kecemasan sosial } \\
\text { tinggi cenderung melakukan strategi } \\
\text { supresi emosi sehingga regulasi } \\
\text { emosinya kaku. }\end{array}$ \\
\hline 14 & $\begin{array}{l}\text { Battista, et. } \\
\text { al., } 2015\end{array}$ & Kanada & $\begin{array}{l}\text { Kuantitatif, } \\
\text { ESM, } n=132\end{array}$ & $\begin{array}{l}\text { Multilevel } \\
\text { Modelling }\end{array}$ & $\begin{array}{l}\text { Penggunaan alkohol menurunkan } \\
\text { state social anxiety (SSA) }\end{array}$ \\
\hline
\end{tabular}




\section{Hasil}

\section{Definisi ESM}

Experience Sampling Methods (ESM) atau diary study adalah metode pengambilan data yang dilakukan secara berulang dalam jangka waktu tertentu menggunakan alat yang khusus dirancang untuk diaplikasikan dan dilakukan kegiatan sehari-hari subyek (Scollon et al., 2003). ESM merupakan metode pengumpulan data yang unik karena data yang diperoleh bisa lebih mendekati pengalaman hidup partisipan (Scollon et al., 2003). Penggunaan ESM dalam penelitian psikologi dinilai cukup menjanjikan karena, jika dibanding dengan single-time measurement tool (skala pengukuran pada umumnya), ESM bisa menggali lebih banyak informasi dan bisa meminimalisir munculnya memory/recall bias (Scollon et al., 2003). ESM juga mungkin digunakan untuk pendekatan penelitian idiographic (bersifat longitudinal mempelajari interaksi within subjek dalam jangka waktu tertentu) maupun nomothetic (bersifat menggeneralisir suatu peristiwa) (Trull \& Ebner-Priemer, 2009).

\section{Prosedur ESM}

Pada umumnya, riset menggunakan ESM berlangsung selama 1-2 minggu dengan rata-rata jumlah pengambilan data antara 2-12 per hari (Scollon et al., 2003). Untuk riset mengenai kesehatan mental, menurut Palmier-Claus et al., (2011), prosedur ESM biasanya berlangsung selama 6 hari dengan rentang waktu pengambilan data mulai dari jam 07.30 hingga 22.30. Hal ini karena pada jam-jam tersebut, diharapkan proses pengambilan data tidak mengganggu waktu istirahat para partisipan, lebih jauh lagi tidak mengganggu kesejahteraan mental/psikologis mereka.

Dalam memutuskan lama pengumpulan data serta banyaknya data yang perlu dikumpulkan selama ESM, peneliti perlu mempertimbangkan beberapa hal, seperti; jumlah observasi yang dibutuhkan untuk estimasi yang stabil, frekuensi kemunculan alami peristiwa/ perilaku yang ditargetkan, beban yang mungkin akan dialami partisipan dan kepatuhan partisipan (Conner, BlissMoreau, \& Barrett, 2003). Jumlah total pengambilan data yang diperlukan bisa saja bervariasi dari tiga data per orang (lihat Myers, Saunders, \& Birjulin, 2004), lima kali sehari selama 7 hari (lihat Scollon, et. al., 2005) atau tujuh kali sehari selama dua minggu (lihat Juslin, et. al., 2008).

Ada tiga tipe ESM berdasarkan waktu pengambilan data (Scollon et al., 2003), yaitu:

a. Interval-contingent sampling

Dalam interval-contingent sampling, partisipan diminta mengisi kuesioner di waktu-waktu yang telah ditentukan sebelumnya (e.g., setiap satu jam sekali atau dua jam sekali pada rentang waktu tertentu). Metode sampling ini sesuai untuk mempelajari pengalaman yang frekuentatif dan cenderung lebih tidak membebani partisipan karena waktu pengambilan data sudah dirancang menyesuaikan dengan jadwal sehari-hari mereka (Conner, et. al., 2003). Akan tetapi, metode sampling ini tidak sesuai untuk mempelajari pengalaman-pengalaman yang rentan terhadap memory bias atau mudah hilang/ dilupakan seiring berjalannya waktu, e.g., emosi dan mood (Conner et al., 2003).

b. Event-contingent sampling

Dalam metode pengambilan sampel ini, partisipan diminta untuk mengisi kuesioner setelah mengalami situasi khusus yang telah ditentukan sebelumnya. (Contoh: mengisi kuesioner mengenai emosi setelah melihat hewan tertentu di kebun binatang (Myers, et. al., 2010), setelah mengalami interaksi sosial pada orang dengan kecemasan sosial (Kashdan \& Farmer, 2014), atau setelah mengkonsumsi alkohol (Battista et al., 2015)). Metode ini lebih sesuai untuk mempelajari pengalamanpengalaman yang jarang dialami oleh partisipan (Conner, et. al., 2003).

\section{c. Signal-contingent sampling}

Signal-contingent sampling memungkinkan subjek penelitian untuk mengisi kuesioner setelah diberikan sinyal alarm yang bersifat random/acak (contoh; Juslin, et. al., 2008). Metode sampling ini sangat sesuai untuk mengukur pengalaman atau variabel yang rentan terhadap memory/recall bias, seperti kognisi dan regulasi emosi (Conner, et. al., 2003). Di sisi lain, metode ini memiliki kelemahan 
utama berupa potensi mengganggu kehidupan sehari-hari partisipan (Conner, et. al., 2003). Hal ini disebabkan oleh pembunyian alarm yang bersifat acak sehingga terkadang kurang sesuai dengan jadwal keseharian para subjek penelitian.

Pemilihan jenis ESM yang digunakan tentu saja disesuaikan dengan kebutuhan penelitian. Hanya saja menurut Scollon, et. al. (2003) perkembangan riset ESM terkini lebih mengutamakan jenis yang ketiga, yaitu signal-contingent sampling. Hal ini karena dengan penggunaan sinyal secara acak, kemungkinan munculnya bias saat pengisian kuesioner bisa diminimalisasi.

Berdasarkan media yang digunakan dalam proses pengambilan data, ESM dibagi menjadi dua jenis (Conner, et. al., 2003; Palmier-Claus, et. al., 2011), yaitu:

\section{a. Paper-and-pencil method}

Metode kertas dan pensil merupakan metode yang paling murah dan mudah penggunaannya (Palmier-Claus, et. al., 2011). Penggunaan metode kertas dan pensil ini memiliki beberapa kekurangan. Kekurangan yang mungkin muncul adalah ketidakmampuan untuk mengukur kepatuhan partisipan (sebagai contoh, benar-benar mengisi kuesioner hanya setelah munculnya sinyal), sulitnya mengacak presentasi item untuk mencegah munculnya item bias, dan kemungkinan munculnya human error dan sampling bias (Barrett \& Barrett, 2001). Metode ini juga tidak akurat dalam melaporkan waktu input data (Palmier-Claus, et. al., 2011)

\section{b. Computerized ESM}

Ada dua alternatif computerized ESM; 1) menggunakan PDA (Personal Digital Assistant) dan 2) menggunakan perangkat/gawai pribadi (handphone) partisipan (Palmier-Claus, et. al., 2011). PDA yang biasa disebut dengan palmtop, hand-held computer atau komputer saku ini menawarkan semua kemudahan computerized ESM, hanya saja PDA sudah jarang digunakan sehingga peneliti membutuhkan biaya yang besar untuk pengadaannya. Penggunaan PDA yang tidak lazim juga mungkin menyulitkan kelompok populasi tertentu yang kurang akrab dengan teknologi ini (PalmierClaus, et. al., 2011).

Sementara itu, penggunaan gawai pribadi partisipan lebih mungkin dilakukan karena selain menawarkan kemudahan computerized ESM secara umum, penggunaan gawai pribadi juga lebih memudahkan partisipan dalam proses pengenalan dan penggunaannya. Meskipun demikian, peneliti juga perlu mempertimbangkan beberapa tantangan penggunaan gawai pribadi, yaitu; mahalnya pembuatan software dan perlunya proses validasi alat ukur lebih lanjut (Palmier-Claus, et. al., 2011).

Menurut Barret dan Barret (2001) computerisasi ESM lebih dianjurkan karena bisa dengan tepat mengontrol pengaturan waktu (timing), meminimalisasi waktu yang dibutuhkan untuk merespon (semakin cepat mengisi, semakin akurat hasil yang diberikan), mengurangi human error, dan menggugah tingkat partisipasi subyek (hal ini dikarenakan ketertarikan sebagian besar orang akan teknologi dan kemudahan yang ditawarkannya).

Di samping banyaknya kemudahan yang ditawarkan oleh computerized ESM, ada beberapa hal yang perlu diperhatikan (Barret \& Barret, 2001). Pertama, penggunaan dan pengaturan perangkat, diantaranya proses membangun software, mengaplikasikannya dalam perangkat, hingga maintenance perangkat supaya bisa meminimalisasi kejadian tidak terduga semacam perangkat yang tiba-tiba mati, data hilang, dll. Kedua, peneliti juga harus mempertimbangkan reaktivitas, beban dan atrisi yang mungkin dialami oleh partisipan.

Beberapa program yang bisa digunakan untuk mendesain ESM adalah ESP (Barret \& Barret, 2001), software pendragon (Conner, et. al., 2003), AndWellness (Hicks et. al., 2010) atau menggunakan jasa programmer profesional (Barret \& Barret, 2001; Conner, et. al., 2003).

\section{Pentingnya Briefing dan Debriefing dalam ESM}

Dua tahapan yang sangat krusial dalam ESM yang perlu diperhatikan oleh peneliti yang tertarik menggunakan metode ini adalah briefing (sebelum) dan debriefing (sesudah). Proses briefing diperlukan untuk membangun hubungan yang baik antara peneliti dengan partisipan, mengisi informed consent, 
serta untuk mensosialisasikan dan mensimulasi penggunaan alat. Briefing penting karena akan menentukan tingkat partisipasi, jadi harus dipastikan bahwa briefing dilakukan secara individu, sehari sebelum memulai prosedur. Hubungan yang baik dengan partisipan juga akan memudahkan komunikasi, sehingga ketika partisipan mengalami masalah, mereka akan mudah mengkonsultasikan masalahnya. Selain itu, briefing yang tepat juga akan memunculkan antusiasme (dengan menjelaskan seberapa penting studi ini misalnya). Dalam briefing juga diharapkan agar melakukan janjian telepon rutin untuk memantau kondisi peserta (Palmier-Claus, et. al., 2011).

Setelah proses pengumpulan data berakhir, peneliti juga perlu menekankan pentingnya debriefing. Dalam debriefing, peneliti perlu mengecek jumlah entri data (apakah jumlah minimalnya sudah terpenuhi atau belum) serta melakukan wawancara singkat untuk menindak lanjuti temuan-temuan yang ambigu dalam entri (Palmier-Claus, et. al., 2011). Selain itu, beberapa peneliti juga menggunakan waktu debriefing untuk memberikan kompensasi kepada partisipan (Battista et al., 2015)

\section{Kelebihan dan Kekurangan ESM}

Berdasarkan penjabaran di atas, bisa disimpulkan bahwa ESM memiliki beberapa keunggulan dibanding metode pengumpulan data kuantitatif lainnya. Pertama, ESM memungkinkan peneliti untuk menganalisis proses interpersonal (between persons situation) dan intrapersonal (within person) sekaligus (Scollon et al., 2003). ESM mampu merekam perubahan eksternal yang terjadi, sehingga metode ini lebih mampu mengukur variabel-variabel yang sifatnya context-dependent (tergatung konteks/situasi) seperti emosi (Juslin, et. al., 2008; Trull \& Ebner-Priemer, 2009), regulasi emosi (O'Toole, et. al., 2014) dan kecemasan sosial (Battista et al., 2015). ESM juga mampu menginvestigasi proses-proses yang terjadi di dalam diri individu berupa hubungan antar variabel (Palmier-Claus, et. al., 2011) maupun model perilaku (Barret \& Barret, 2001) dan kaitannya dengan waktu secara lebih mendetail. Sebagai contoh, dalam beberapa penelitian yang telah dilakukan, ESM mampu memberikan informasi mengenai munculnya dua beberapa emosi yang berbeda dalam waktu yang bersamaan setelah diberikan stimulus tertentu (Scollon et al., 2003; Juslin, et. al. 2008; Myers, et. al., 2010).

Kedua, ESM memiliki validitas ekologis yang besar karena responnya selalu terkait dengan momen yang saat itu juga sedang dialami subyek (Barret \& Barret, 2001; Scollon et al., 2003; Palmier-Claus, et. al., 2011). Validitas ekologis merupakan hal yang penting dalam sebuah penelitian terutama penelitian yang bertujuan untuk intervensi klinis karena dalam penanganan kasus klinis, seseorang perlu mendapatkan informasi mengenai aktivitas, situasi mood, dan perilaku yang sifatnya sehari-hari untuk kemudian ditentukan bagaimana dan kapan sebaiknya perlakuan dilakukan untuk menangani gejalagejala yang diperlihatkan oleh pasien. (Trull \& Ebner-Priemer, 2009). Contoh penggunaan ESM sebagai metode untuk menguji validitas ekologis suatu penelitian eksperimen telah dilakukan oleh Battista et al., (2015) yang membuktikan dampak konsumsi alkohol terhadap penurunan kecemasan di latar alamiah individu.

Selanjutnya, ESM cenderung lebih baik dalam meminimalisasi recall bias karena prosedur standarnya mengharuskan jarak antara sinyal dan respon yang dekat (i.e., < 15 menit (Scollon et al., 2003; Palmier-Claus, et. al., 2011)) sehingga prosedur ini benar-benar membutuhkan proses kognitif yang sangat sederhana (Trull \& Ebner-Priemer, 2009). Barret dan Barret (2001) bahkan mengatakan bahwa sebegitudekatnya jarak antara sinyal dan respon menyebabkan data ESM tidak berasal dari ingatan tetapi dari kesadaran individu. Meskipun demikian, pada kasus tertentu, jarak antara beep (sinyal) dengan respon masih bisa disesuaikan. Misalnya pada penelitian Battista et al., (2015), jarak maksimal pemberian respon setelah sinyal adalah dua jam karena penelitian tersebut merupakan penelitian lanjutan dari sebuah studi eksperimental yang juga menetapkan interval waktu dua jam antara pemberian stimulus dan respon.

Keempat, ESM memungkinkan peneliti untuk menggunakan metode asesmen yang beragam (Scollon et al., 2003). Keberagaman metode asesmen memungkinkan peneliti untuk mendapatkan gambaran perilaku empiris yang lebih menyeluruh melalui proses pengambilan data baik itu cross- 
sectional maupun longitudinal, meneliti perilaku yang bisa jadi tidak etis jika dilakukan dalam konteks laboratorium (contoh: eksperimen yang berkaitan dengan phobia, merangsang phobia seseorang cenderung tidak etis dan harus dilakukan secara berhati-hati), mengetes validitas generalisasi dengan meneliti perilaku dalam jangka waktu yang cenderung lebih panjang (Barret \& Barret, 2001), dan karena sifat data ESM sangat berkaitan dengan waktu, metode ini dapat digunakan untuk mengembangkan Intelligent Real Time Therapy (IRRT) untuk mencegah permasalahan kompleks seperti bunuh diri (Kelly et al., 2012).

Sayangnya, ada beberapa hal yang masih perlu dipertimbangkan sebelum seorang peneliti mengaplikasikan ESM ke dalam penelitiannya. ESM akan sangat sulit diaplikasikan dalam penelitian jangka panjang. Hal ini berkaitan dengan permasalahan terkait partisipan seperti self-selction bias, atrisi, motivasi dan keterbatasan lain, serta terkait dengan managemen data maupun teknik analisis data yang digunakan (Scollon et al., 2003). Rata-rata jangka waktu pengambilan data ESM adalah 1-2 minggu dengan kemunculan 2 hingga 12 sinyal per hari. Hal ini tentu saja akan menimbulkan rasa lelah dan kehidupan pribadi subyek penelitian pun bisa terganggu (Scollon et al., 2003). Tidak heran bila kesuksesan proses pengambilan data ESM sangat bergantung pada level motivasi partisipan (Scollon et al., 2003). Seringkali motivasi harus didukung dengan kompensasi yang sesuai, namun pemberian kompensasi merupakan hal yang problematis secara etika. Sehingga, Palmier-Claus, et. al., (2011) menekankan bahwa peneliti harus serius dalam melakukan briefing dan konsisten dalam menjaga komunikasi dengan partisipan. Selain itu, penyederhanaan pertanyaan dan jumlah aitem yang sedikit juga diharapkan dapat menjaga meminimalisir kelelahan atau rasa terganggu yang mungkin dialami partisipan (Scollon et al., 2003).

Prosedur ESM juga dapat memunculkan permasalahan terkait data. Dengan jangka waktu dan frekuensi pengambilan data sesuai dengan yang disebutkan di bagian sebelumnya, data yang diperoleh cenderung banyak dan kompleks. Data juga mungkin sekali tidak lengkap karena bisa saja sinyal muncul di situasi yang tidak tepat (pada prosedur signal-contingent sampling) (Scollon et al., 2003). Jumlah maksimal data hilang yang dapat ditoleransi sejauh ini besarnya bervariasi. Misalnya, tiga kali (Kashdan \& Farmer, 2014), atau tidak ada syarat minimal entri data (Battista et al., 2015).

Ada beberapa metode yang bisa dilakukan untuk menganalisis data ESM. Misalnya Multi-Level Modelling (MLM) (Myin-Germeys et al., 2003; Palmier-Clauss, et. al., 2011; Battista et al., 2015), ThreeWay Anova (Kashdan \& Farmer, 2014), Selain itu, untuk mempermudah proses analisis, pengklasteran data menjadi lapisan-lapisan (layers) tertentu juga sangat disarankan (Battista et al., 2015). Misalnya membagi data menjadi dua lapisan, yaitu lapisan data between person (data hasil pengukuran trait/variabel) dan lapisan within person (rekaman data harian per subyek) (O'Toole et al., 2014).

Selain beberapa hal di atas, reaktivitas subyek juga perlu dipertimbangkan. Menurut Scollon, et. al., (2003) asesmen yang dilakukan berulang-ulang dapat menstimulus partisipan untuk terlalu memikirkan kondisinya (inner state). Sehingga proses internal subyek bisa jadi berubah sesuai dengan apa yang ada di pikirannya. Perubahan ini bisa menjadi kontra produktif terutama jika penelitian ESM yang dilakukan adalah mengenai mood atau emosi negatif. Peneliti perlu mengantisipasi munculnya responrespon yang tidak diinginkan seperti kecemasan, perasaan depresi, dll.

Penggunaan ESM dalam riset Psikologi kuantitatif memungkinkan peneliti untuk melihat permasalahan dengan sudut pandang yang lebih luas. Penelitian yang sifatnya cross-sectional dan longitudinal bisa dilakukan secara bersama-sama menggunakan ESM. Meskipun ada beberapa hal yang masih menjadi catatan terkait tantangan penggunaan ESM, Conner et al., (2003) meyakinkan bahwa metode ini sangat mungkin dilakukan dengan syarat; 1) keberadaan tim riset yang kuat (umumnya riset ESM membutuhkan 2 pemimpin dan 1 asisten untuk mengawasi 5-10 partisipan) dan 2) sumber daya finansial yang mencukupi untuk memberi kompensasi. Meskipun demikian, Conner, et. al., (2003) menambahkan bahwa selain kompensasi, kemampuan peneliti untuk memotivasi subyek juga sangat penting bagi keberlangsungan riset ESM. 


\section{Kesimpulan dan Rekomendasi}

Aplikasi Experience Sampling Method (ESM) atau Diary Study di Indonesia dapat memperkaya khazanah keilmuan psikologi di Indonesia. ESM merupakan salah satu metode pengambilan data yang dikembangkan untuk mampu mengambil data secara berkala pada rentang waktu tertentu. Karena sifat datanya yang berkaitan dengan waktu (time-related), ESM diketahui sangat sesuai untuk meneliti variabel-variabel yang bersifat context-dependent (tergantung pada konteks), seperti: mood, emosi, regulasi emosi, dan kecemasan sosial. Prosedur ESM pada umumnya ada tiga, yakni interval-contingent sampling, event-contingent sampling, dan signal-contingent sampling. Sejauh ini prosedur yang ketiga merupakan yang paling dapat meminimalkan bias karena sinyal dimunculkan secara acak. Selain itu, terkait dengan administrasinya, ESM juga bisa dilakukan melalui paper and pencil method dan melalui program yang terintegrasi dalam computer atau ponsel pintar. Perkembangan teknologi yang pesat memungkinkan prosedur yang kedua untuk bisa dilakukan secara lebih luas.

ESM memiliki kelebihan yang dapat memfasilitasi kekurangan baik itu penelitian survey maupun eksperimen. Pertama ESM mampu menganalisis situasi/proses yang bersifat intra-individual (within person) maupun ekstra-individual (between-person). Kedua, ESM memiliki validitas ekologis yang bagus serta dapat meminimalkan recall bias karena respon subyek diberikaan sesaat setelah sinyal dibunyikan dan cenderung mengukur situasi yang saat itu tengah di alami oleh subyek. Kemudian, ESM juga mampu diaplikasikan dengan metode asesmen yang beragam untuk melihat permasalahan secara lebih menyeluruh. Meskipun demikian, beberapa hal perlu diperhatikan sebelum menggunakan ESM dalam penelitian. Pertama terkait dengan keikutsertaan subyek; waktu pengambilan data yang cukup lama dan berkala bersifat rentan terhadap atrisi dan keikutsertaan peserta sangat tergantung pada motivasi. Proses itu juga menghasilkan data yang banyak kompleks sehingga memunculkan tantangan tersendiri terkait kelengkapan, managemen dan analisis data. Tantangan lain dalam ESM adalah kemungkinan munculnya reaktivitas subyek setelah mengisi data secara berulang. Hal-hal untuk meminimalkan permasalahan di atas telah didiskusikan.

Oleh karena ESM merupakan hal yang baru dalam penelitian kuantitatif di Indonesia, penulis berharap makin banyak peneliti mempublikasikan karya terkait metode ini. Sebelum diaplikasikan dalam penelitian lapangan, diharapkan studi literatur yang komprehensif lebih banyak dilakukan untuk memperkuat penggunaan metode penelitian ini. Sehingga diharapkan di masa mendatang, akan banyak bermunculan penelitian-penelitian psikologi yang menggunakan ESM/Diary Studies serta benar-benar melakukannya secara tepat sesuai prosedur yang sudah disepakati secara global.

\section{Daftar Pustaka}

Adila, W., Rinjani, M., \& Cinderela, P. (2019). Tingkat pengetahuan remaja tentang personal hygiene. Journal of Psychological Perspective, 1(2), 59-66.

Barrett, L. F., \& Barrett, S. P. (2001). An introduction to computerized experience sampling in psychology, 19(2), 175-185.

Battista, S. R., Mackinnon, S. P., Sherry, S. B., Barrett, S. P., MacNevin, P. D., \& Stewart, S. H. (2015). Does alcohol reduce social anxiety in daily life? A 22-day experience sampling study. Journal of Social and Clinical Psychology, 34(6), 508-528. https://doi.org/10.1521/sscp.2015.34.6.508

Conner, T. S., Bliss-Moreau, E., \& Barrett, L. F. (2003). A practical guide to experience sampling procedures. Journal of Happiness Studies, 4, 53-78.

Creswell, J. W. (2014). Research Design: Qualitative, Quantitative and Mixed Methods Approach. Thousand Oaks, California: Sage Publications, Inc. 
Fowler, F. J. (2014). Survey Research Methods (5th ed.). Thousand Oaks, California: Sage Publications, Inc.

Gotlin, M. J., Kingery, M. T., Baron, S. L., McCafferty, J., Jazrawi, L. M., \& Meislin, R. J. (2020). Recall Bias in Retrospective Assessment of Preoperative Patient-Reported American Shoulder and Elbow Surgeons Scores in Arthroscopic Rotator Cuff Repair Surgery. American Journal of Sports Medicine, 48(6), 1471-1475. https://doi.org/10.1177/0363546520913491

Hicks, J., Ramanathan, N., Falaki, H., Longstaff, B., Parameswaran, K., Monibi, M., ... Estrin, D. (2010). AndWellness: an open mobile system for activity and experience sampling. In Proceedings of Wireless Health 2010 (pp. 34-43). https://doi.org/10.4108/icst.pervasivehealth.2012.248705

Hipp, L., Bünning, M., Munnes, S., \& Sauermann, A. (2020). Problems and pitfalls of retrospective survey questions in COVID-19 studies. Survey Research Methods, 14(2), 109-114. https://doi.org/10.18148/srm/2020.v14i2.7741

Juslin, P. N., Liljeström, S., Västfjäll, D., Barradas, G., \& Silva, A. (2008). An Experience Sampling Study of Emotional Reactions to Music: Listener, Music, and Situation. Emotion, 8(5), 668-683. https://doi.org/10.1037/a0013505

Kashdan, T. B., \& Farmer, A. S. (2014). Differentiating Emotions Across Contexts: Comparing Adults with and without Social Anxiety Disorder Using Random, Social Interaction, and Daily Experience Sampling. Emotion, 14(3), 629-638. https://doi.org/10.1037/a0035796.Differentiating

Kelly, J., Gooding, P., Pratt, D., Ainsworth, J., Welford, M., \& Tarrier, N. (2012). Intelligent real-time therapy: Harnessing the power of machine learning to optimise the delivery of momentary cognitivebehavioural interventions. Journal of Mental Health, 21(4), 404-414. https://doi.org/10.3109/09638237.2011.638001

Lerner, R. M., \& Schmid Callina, K. (2014). Relational developmental systems theories and the ecological validity of experimental designs: Commentary on freund and isaacowitz. Human Development, 56(6), 372-380. https://doi.org/10.1159/000357179

Muarif, A. K., \& Adiyanti, M. G. (2020). Emotional Intelligence training untuk mereduksi burnout pada anggota Kepolisian Republik Indonesia. Journal of Psychological Perspective, 2(1), 13-24.

Myers, O. E., Saunders, C. D., \& Birjulin, A. A. (2004). Emotional Dimensions of Watching Zoo Animals: An Experience Sampling Study Building on Insights from Psychology. Curator: The Museum Journal, 47(3), 299321. https://doi.org/10.1111/1.2151-6952.2004.tb00127.x

Myin-Germeys, I., Peeters, F., Havermans, R., Nicolson, N. A., DeVries, M. W., Delespaul, P., \& Van Os, J. (2003). Emotional reactivity to daily life stress in psychosis and affective disorder: An experience sampling study. Acta Psychiatrica Scandinavica, 107(2), 124-131. https://doi.org/10.1034h.1600-0447.2003.02025.x

Neuman, W. L. (2014). Social Research Methods: Qualitative and Quantitative Approaches. Essex: Pearson Education Limited. https://doi.org/10.2307/3211488

O’Toole, M. S., Jensen, M. B., Fentz, H. N., Zachariae, R., \& Hougaard, E. (2014). Emotion differentiation and emotion regulation in high and low socially anxious individuals: An experience-sampling study. Cognitive Therapy and Research, 38(4), 428-438. https://doi.org/10.1007/s10608-014-9611-2

Ottenstein, C., \& Lischetzke, T. (2020). Recall bias in emotional intensity ratings: investigating person-level and event-level predictors. Motivation and Emotion, 44(3), 464-473. https://doi.org/10.1007/s11031-019-09796-4

Palmier-Claus, J. E., Myin-Germeys, I., Barkus, E., Bentley, L., Udachina, A., Delespaul, P. A. E. G., ... Dunn, G. (2011). Experience sampling research in individuals with mental illness: Reflections and guidance. Acta Psychiatrica Scandinavica, 123(1), 12-20. https://doi.org/10.1111/1.1600-0447.2010.01596.x

Prasandi, A., \& Diana, H. (2020). Perempuan Dewasa di Kecamatan Sukoharjo Kabupaten Pringsewu. Journal of Psychological Perspective, 2(1), 25-39.

Schmuckler, M. (2001). What is Ecological Validity? Infancy, 2(4), 419-436.

Scollon, Christie N., Kim-Prieto, C., \& Scollon, C. N. (2003). Experience Sampling: Promises and Pitfalls, Strengths and Weaknesses. Journal of Happiness Studies, 4(1), 5-34. https://doi.org/10.1023/a:1023605205115

Scollon, Christie Napa, Diener, E., Oishi, S., \& Biswas-Diener, R. (2005). An experience sampling and cross-cultural 
investigation of the relation between pleasant and unpleasant affect. Cognition and Emotion, 19(1), 27-52. https://doi.org/10.1080/02699930441000076

Trull, T. J., \& Ebner-Priemer, U. W. (2009). Using Experience Sampling Methods/Ecological Momentary Assessment (ESM/EMA) in Clinical Assessment and Clinical Research: Introduction to the Special Section. Psychol Assess, 21(4), 457-462. https://doi.org/10.1111/1464-0597.00091 